\title{
PERAN BRAND IMAGE MEMEDIASI PENGARUH KREDIBILITAS CELEBRITY ENDORSER TERHADAP BRAND LOYALTY
}

\author{
Putu Arina Indah Puspita Dewi ${ }^{1}$ \\ Ni Made Purnami ${ }^{2}$
}

\author{
${ }^{1,2}$ Fakultas Ekonomi dan Bisnis Universitas Udayana (Unud), Bali, Indonesia \\ Email:arina.dewi@ymail.com
}

\begin{abstract}
ABSTRAK
Penelitian ini bertujuan untuk menjelaskan peran brand image memediasi pengaruh kredibilitas celebrity endorser terhadap brand loyalty. Penelitian ini diharapkan dapat memberikan kontribusi empiris tentang pengaruh antara variable kredibilitas celebrity endorser, brand image dan brand loyalty bagi perkembangan ilmu pengetahuan dan menjadi bahan pertimbangan bagi manajemen perusahaan. Penelitian ini dilakukan di Kota Denpasar dengan melibatkan 100 responden yang menggunakan smartphone merek OPPO melalui metode purposive sampling. Pengumpulan data menggunakan penyebaran kuesioner. Teknik analisis data yang digunakan ialah analisis jalur dan uji sobel dimana sebelumnya telah di uji dahulu menggunakan uji asumsi klasik. Hasil penelitian menemukan bahwa kredibilitas celebrity endorser berpengaruh positif dan signifikan terhadap brand image dan brand loyalty. Brand image berpengaruh positif dan signifikan terhadap brand loyalty dan mampu memediasi secara signifikan pengaruh kredibilitas celebrity endorser terhadap brand loyalty. Penggunaan seorang celebrity endorser yang memilki kredibilitas baik akan meningkatkan brand image sehingga dapat menjaga brand loyalty.
\end{abstract}

Kata kunci: kredibilitas celebrity endorser, brand image, brand loyalty

\section{ABSTRACT}

This study aims to explain the role of brand image mediating the influence of celebrity endorser's credibility on brand loyalty. This research is expected to provide empirical contributions about the influence between the variable credibility of celebrity endorser, brand image and brand loyalty for the development of science and become a consideration for company management. This research was conducted in Denpasar City by involving 100 respondents who used the OPPO brand smartphone through a purposive sampling method. Data collection using questionnaires. The data analysis technique used is path analysis and sobel test where previously tested using the classic assumption test. The results of the study found that the credibility of the celebrity endorser had a positive and significant effect on brand image and brand loyalty. Brand image has a positive and significant effect on brand loyalty and is able to significantly mediate the influence of celebrity endorser's credibility on brand loyalty. The use of a celebrity endorser who has good credibility will increase the brand image so that it can maintain brand loyalty.

Keywords: credibility of celebrity endorser, brand image, brand loyalty 


\section{PENDAHULUAN}

Perkembangan teknologi yang semakin cepat mempengaruhi penggunaan teknologi dibidang telekomunikasi yang cukup pesat khususnya telekomunikasi seluler di Indonesia. Smartphone merupakan media dalam penggunaan teknologi telekomunikasi seluler yang saat ini paling cepat mengalami perkembangan, hal ini dapat dilihat dari banyaknya produsen produk smartphone yang menawarkan berbagai tipe baru berbeda dari tipe sebelumnya. Saat ini, sudah banyak masyarakat baik dari berbagai lapisan mampu mengakses telekomunikasi menggunakan media smartphone (Kurniawan, 2016; Sari dan Santika, 2017)

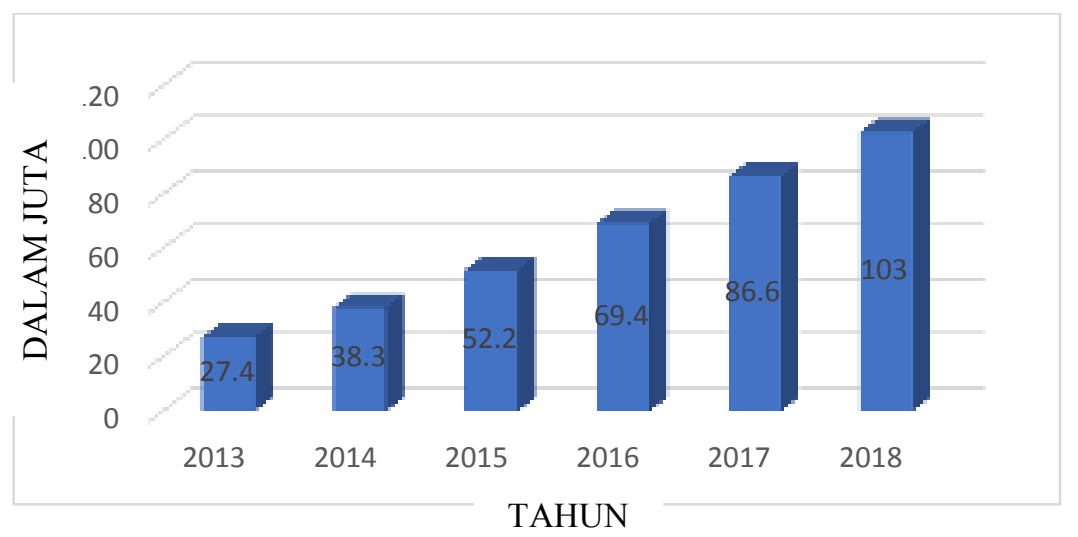

Gambar 1. Jumlah Pengguna smarthpone di Negara Indonesia (Dalam Juta) Sumber : Lembaga Riset Digital Marketing, Emarketer, 2015

Berdasarkan Grafik 1. penggunaan smartphone di Indonesia terus meningkat setiap tahunnya secara signifikan. Kemunculan smartphone yang cukup pesat berganti di kalangan konsumen menyebabkan persaingan antara produsen satu dengan yang lain semakin ketat dalam usaha produsen untuk mendapatkan konsumen dan menjaga loyalitas yang dimiliki konsumen. Loyalitas diakui sebagai faktor yang merupakan prasyarat kelangsungan sebuah perusahaan yang penting 
khususnya ditengah ketatnya persaingan, salah satu merek smartphone yang sering muncul di masyarakat ialah merek OPPO.

OPPO merupakan salah satu merek smartphone yang berasal dari China. Smartphone OPPO sendiri sudah mulai memasuki pasar Indonesia sejak tahun 2013. OPPO merupakan smartphone yang memiliki kelebihan pada teknologi selfie expert dan camera phone, kedua hal ini yang menjadi tagline kuat smartphone OPPO untuk menarik perhatian konsumen dan menjaga loyalitas konsumen.

Loyalitas merek memiliki pengaruh yang sangat penting bagi perusahaan karena melibatkan kerentanan konsumen terhadap serangan pesaing. Seorang konsumen yang sangat loyal terhadap sebuah merek barang maupun jasa tidak akan mudah untuk bisa memindahkan pembeliannya ke merek lain, hal inilah yang dapat menunjukkan loyalitas konsumen terhadap merek tersebut tinggi (Rodique, dan Rahanatha, 2018; Kurniawan, 2016).

OPPO sudah mengeluarkan beberapa tipe smartphone yang disukai dan diinginkan konsumen demi menjaga loyalitas konsumen. Tahun 2017 tipe yang dikeluarkan oleh OPPO ialah F5, F5 edisi 6GB dan F5 Youth. Smartphone ini terbukti telah menjual 48 ribu unit dalam 7 hari penjualan di Indonesia.

Tabel 1.

Data penjualan smartphone di tahun 2017 di Dunia.

\begin{tabular}{ccccccc}
\hline Periode & Apple & Samsung & Huawei & Xiaomi & OPPO & Lainnya \\
\hline 2016Q4 & $18,2 \%$ & $18,0 \%$ & $10,6 \%$ & $3,3 \%$ & $7,3 \%$ & $42,5 \%$ \\
$2017 \mathrm{Q} 1$ & $14,7 \%$ & $23,3 \%$ & $10,0 \%$ & $4,3 \%$ & $7,5 \%$ & $40,2 \%$ \\
$2017 \mathrm{Q} 2$ & $11,8 \%$ & $22,9 \%$ & $11,1 \%$ & $6,2 \%$ & $8,0 \%$ & $40,0 \%$ \\
2017Q3 & $12,4 \%$ & $22,1 \%$ & $10,4 \%$ & $7,5 \%$ & $8,1 \%$ & $39,5 \%$ \\
\hline
\end{tabular}

Sumber: IDC Quarterly Mobile Phone Tracker - Sejarah Terakhir, 2017.

Penjualan smartphone OPPO pada tahun 2016 kuartal empat sebesar 7,3\%. Setiap tahunnya pada tahun 2017 dimulai dari kuartal 1 hingga 3 terus mengalami 
peningkatan. Hal ini membuktikan konsumen mulai aware dan terbuka terhadap keberadaan merek smartphone asal China tersebut. OPPO berhasil bergerak melampaui pasar domestik Cina dan mendapatkan pijakan di negara-negara Asia lainnya seperti India, Indonesia, dan Vietnam.

Minat masyarakat terhadap smartphone merek OPPO di Indonesia sendiri terus mengalami peningkatan yang signifikan dilihat dari data yang diperoleh pada laman TBI yang mana top brand indeks smartphone merek OPPO di Indonesia sejak tahun 2015 mengalami kenaikan berdasarkan gambar 2. Meskipun indeks smartphone merek OPPO masih kalah jauh dibandingkan pesaingnya yang lain namun OPPO berhasil menjaga indeks yang dimiliki dan meningkatkannya di Indonesia. Hal ini membuktikan OPPO masih mendapatkan loyalitas pelanggannya di Indonesia.

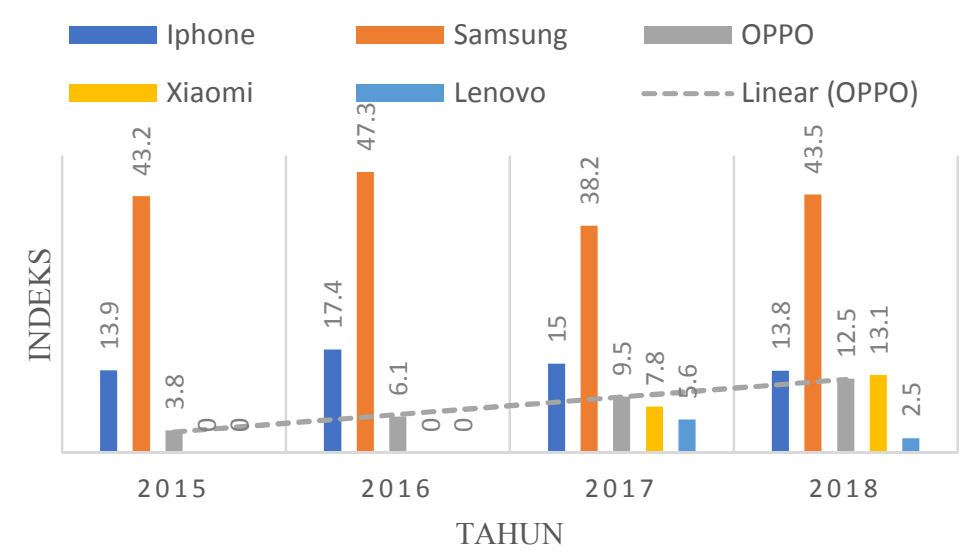

Gambar 2. Data TBI Smartphone di Indonesia Sumber : www.topbrand-award.com, 2018

Menentukan target pasar yang tepat dapat memudahkan produk untuk dapat diterima oleh calon konsumen. Salah satu strateginya ialah dengan melakukan promosi. Promosi merupakan insentif jangka pendek untuk mendorong pembelian 
atau penjualan jasa (Kotler dan Armstrong, 2014: 214). Iklan merupakan semua bentuk terbayar atas presentasi nonpribadi dan promosi ide, barang ataupun jasa oleh sponsor yang jelas. Sebuah perusahaan dalam membuat iklannya perlu mempertimbangkan media iklan yang digunakan dan sosok yang akan membintangi iklan tersebut atau sering disebut celebrity endorser. Celebrity endorser adalah orang yang dikenal luas oleh masyarakat dan memanfaatkan identifikasi tersebut untuk mendukung produk dalam iklan. Celebrity endorser merupakan sosok yang menarik dan mampu dalam mengiklankan produk, memiliki kredibilitas yang baik sehingga dapat menumbuhkan niat beli pada orang yang melihat iklan dan membeli produk yang diiklankan. Seorang celebrity endorser agar dapat dipercaya oleh calon konsumennya harus memiliki kredibilitas. Kredibilitas celebrity endorser merupakan kemampuan seorang selebriti dalam menyampaikan pesan atau memberikan informasi dengan baik dan dapat dipercaya (Arsita dan Purnami, 2015). Penggunaan selebriti endorser yang memiliki kredibilitas dalam sebuah iklan juga diupayakan untuk memperoleh keberhasilan membangun citra merek (Apejoye, 2013).

Iklan adalah alat yang berpengaruh yang dapat menyakinkan pelanggan dan menyampaikan informasi ke pasar. Era kompetisi di pasar semakin bertambah, karenanya organisasi harus memprioritaskan dan memfokuskan kembali upaya pada strategi pemasaran yang bernilai tambah. Salah satu strategi ialah dengan melibatkan selebritas dalam periklanan (Ugwuanyi, Okeke, dan Emezue, 2018). Untuk lebih meningkatkan daya tarik promosi yang meyakinkan, para produsen sangat bergantung pada penggunaan selebriti dan orang-orang terkenal sebagai 
pendukung produk mereka (Aziz, 2013). Celebrity Endorser merupakan sosok yang menarik dan mampu dalam mengiklankan produk, memiliki kredibilitas yang baik sehingga dapat menumbuhkan niat beli pada orang yang melihat iklan dan membeli produk yang diiklankan (Sharif, Raza dan Rehman, 2011). Pentingnya dukungan selebriti telah dikenal dengan baik dalam pemasaran modern (Baniya, 2017).

Tahun 2010 OPPO melakukan promosi di Thailand dengan menggunakan Boyband asal Korea Selatan 2PM di Indonesia sendiri OPPO mulai menggunakan celebrity endorser sejak tahun 2015 yang diawali oleh Isyana Sarasvati. Celebrity endorser lain yang digunakan oleh OPPO antara lain Raline Shah, Chelsea Islan, Raisa, Rio Haryanto dan Ayu Ting Ting (Wikipedia.com).

Pemilihan Chelsea Islan sebagai celebrity endorser dimulai sejak munculnya tipe OPPO F5 series di tahun 2017. Chelsea Islan dianggap mampu mewakili target dari konsumen yaitu wanita muda dan sangat aktif di media sosial sesusai dengan Tagline baru OPPO "Capture The Real You". Chelsea Islan dianggap berani dalam menunjukkan dirinya yang sebenarnya di media sosial terlepas dari profesinya sebagai seorang artis.

Menurut Shimp (2010) kredibilitas selebriti sebagai sumber informasi sangat potensial mempengaruhi persepsi konsumen atas informasi yang disampaikan. Kredibilitas celebrity endorser merupakan salah satu faktor yang menentukan loyalitas merek yang diwakili oleh selebriti tersebut. Spry dan Pappu (2011) mengatakan dalam penelitiannya semakin tinggi kredibilitas celebrity endorser, semakin tinggi kemungkinan iklan mencipakan loyalitas merek untuk produk yang dipromosikan oleh selebriti. 
Penggunaan selebriti untuk mempromosikan sebuah produk harus sesuai dengan ciri dan kebiasaan dari endorser tersebut. Sosok celebrity endorser dapat mendukung efektifitas penyampaikan pesan melalui iklan dan membangun citra positif dalam benak konsumen. Citra merek ialah persepsi emosional atau rasional, dimana konsumen dapat memiliki persepsi terhadap merek sebagai suatu yang berkualitas dan praktis serta persepsi bahwa merek tersebut menambahkan semacam status kepada konsumen yang menggunakannya (Belic et al., 2012). Tantangan terbesar yang harus dilakukan oleh pemasar ialah membentuk citra merek yang kuat. Terlebih berbagai macam produk dalam satu kategori dengan kualitas produk yang sudah menjadi standar dan dapat dengan mudah ditiru dan dimiliki oleh siapapun mulai muncul mengakibatkan sulitnya suatu perusahaan sulit untuk mempertahankan diri sebagai pemimpin pasar. Perusahaan untuk mengatasi penetrasi pasar yang dilakukan competitor dan tetap menjaga pangsa pasarnya, salah satu caranya ialah dengan membentuk citra merek yang kuat. Tanpa adanya citra merek yang positif dan kuat akan sulit bagi perusahaan untuk menarik pelanggan baru dan mempertahankan yang sudah ada (Wijanarko, Suharyono dan Arifin, 2016 ; Rizan, Basrah dan Yusiyana, 2012).

Penelitian yang dilakukan oleh Kurniawan (2016) mengungkapkan brand image berpengaruh positif terhadap loyalitas pengguna smartphone. Penelitian yang dilakukan oleh Ratri (2017) mengungkapkan hal yang serupa dimana citra merek dengan loyalitas merek memiliki hubungan yang sangat signifikan, semakin meningkatnya citra merek akan diikuti dengan meningkatnya loyalitas merek terhadap operator seluler yang digunakan. 
Penelitian yang dilakukan oleh Komala (2017) mengungkapkan hal yang serupa bahwa kredibilitas celebrity endorser berpengaruh positif dan signifikan terhadap brand image. Penelitian yang dilakukan Rini (2012) yang menyatakan ada pengaruh positif dan signifikan variabel visibilitas, kredibilitas, daya tarik dan kekuatan terhadap pembentukan citra merek Honda Vario. Penelitian yang dilakukan oleh Wang dan Tsai (2014) mengungkapkan kredibilitas celebrity endorser mempunyai pengaruh yang positif dan signifikan terhadap brand image. Penelitian lain dilakukan oleh Putra dan Sulistyawati (2015) mengungkapkan celebrity endorser berpengaruh positif dan signifikan terhadap brand image.

Pengaruh kredibilitas celebrity endorser terhadap loyalitas dibuktikan melalui penelitian Dix, Ian dan Sonia, (2010) dalam penelitiannya menemukan pengaruh positif dan signifikan endorser atlet olah raga terhadap loyalitas merek pada konsumen usia remaja di Australia Barat. Penelitian yang dilakukan oleh Agung (2017) mengungkapkan hal yang berbeda dimana pada hasil temuan penelitian tersebut menunjukkan bahwa kenaikan pada kredibilitas celebrity endorser akan menaikkan loyalitas namun tidak signifikan.

Upaya yang dapat dilakukan untuk bertahan dalam persaingan pasar demi mendapatkan loyalitas adalah dengan membentuk brand image (Sujana \& Giantari, 2017). Alasan memasukkan variable pemediasi brand image karena brand image yang kuat tentunya dapat meningkatkan loyalitas terhadap merek, brand image merupakan citra perusahaan yang sangat berharga karena dengan memiliki citra yang baik image perusahaan dimata konsumen juga semakin baik. Produk yang 
diperkenalkan oleh seorang selebriti akan menarik perhatian konsumen sehingga membentuk image dimata konsumen (Wijanarko, 2016).

Penelitian yang dilakukan oleh Sujana dan Giantari (2017) mengungkapkan celebrity endorser berpengaruh positif terhadap brand image dari minuman merek You C 1000, adanya brand image dan kredibilitas celebrity endorser dapat memerankan posisi yang vital untuk membawa sebuah merek agar dikenal luas oleh masyarakat. Image baik yang dimiliki oleh suatu produk akan lebih mudah diingat konsumen sehingga pada akhirnya akan berniat untuk membeli sebuah produk. Berdasarkan research gap yang terdapat pada variabel kredibilitas celebrity endorser, brand image dan brand loyalty serta penelitian yang telah dilakukan sebelumnya menyebabkan ditariknya permasalahan mengenai pengaruh kredibilitas celebrity endorser terhadap brand loyalty pada merek smartphone OPPO di Kota Denpasar dengan menggunakan brand image sebagai variabel pemediasi.

Tujuan dari penelitian ini adalah untuk menganalisis pengaruh kredibilitas celebrity endorser terhadap brand loyalty, untuk menganalisis pengaruh kredibilitas celebrity endorser terhadap brand image, untuk menganalisis pengaruh brand image terhadap brand loyalty, untuk menganalisis peran brand image dalam memediasi pengaruh kredibilitas celebrity endorser terhadap brand loyalty pada merek smartphone OPPO di Kota Denpasar.

Diharapkan penelitian ini dapat menjadi bahan pertimbangan dan bahan masukan bagi manajemen perusahaan OPPO dalam memasarkan produknya dengan strategi dalam penggunaan kredibilitas celebrity endorser dan brand image 
dalam menumbuhkan brand loyalty. Sebagai bahan penelitian untuk memberikan pengetahuan serta wawasan yang lebih luas untuk memperjelas pengaruh akan peran brand image dalam memediasi kredibilitas celebrity endorser terhadap brand loyalty.

Menurut Spry, Pappu dan Cornwell (2011) mengatakan dalam penelitiannya semakin tinggi kredibilitas celebrity endorser, semakin tinggi kemungkinan iklan mencipakan loyalitas merek untuk produk yang dipromosikan oleh selebriti. Popularitas dan eksistensi selebritis dalam melakukan celebrity endorsement untuk suatu produk mampu mempengaruhi tingkat kepercayaan konsumen terhadap produk tersebut dan menumbuhkan loyalitas merek. Berdasarkan uraian diatas dikatakan bahwa Celebrity Endorsement memiliki pengaruh yang signifikan terhadap loyalitas merek (Audi,Razan dan Khalil, 2015). Penelitian yang dilakukan oleh Lazarecic (2011) yang meneliti mengenai perilaku pada konsumen usia remaja, menemukan hubungan yang positif signifikan antara celebrity endorser terhadap loyalitas. Penelitian yang dilakukan oleh Agung, Solikhah dan Boby (2017) mengungkapkan hal yang sebaiknya dimana kredibilitas celebrity endorser tidak terbukti berpengaruh positif terhadap loyalitas.

Berdasarkan hasil penelitian sebelumnya, hipotesis yang dapat diajukan dalam penelitian ini adalah:

$\mathrm{H}_{1} \quad$ : Kredibilitas celebrity endorse berpengaruh positif dan signifikan terhadap brand loyalty

Penelitian yang dilakukan oleh Komala, Anggun dan Titin (2017) mengungkapkan bahwa kredibilitas celebrity endorser berpengaruh positif dan signifikan terhadap brand image, penelitian ini dilakukan pada konsumen produk 
wardah di Purworejo. Penelitian yang dilakukan oleh Putra dan Sulistyawati (2015) yang menguji tentang peran brand image dalam memediasi pengaruh celebrity endorser pada sepatu basket Nike Kobe di Kota Denpasar diperoleh analisis dimana celebrity endorser berpengaruh positif dan signifikan terhadap brand image, yang berarti dengan semakin baiknya credibility, attractiveness, expertise dan trustworthiness seorang celebrity endorser maka akan meningkatkan brand image yang dimiliki produk. Lomboan (2013) menyatakan dalam penelitiannya bahwa kredibilitas celebrity endorser memiliki pengaruh yang paling signifikan terhadap citra merek yang menunjukkan bahwa ada hubungan yang kuat antara kredibilitas dan citra merek.

Berdasarkan pemikiran diatas, hipotesis yang dapat diajukan dalam penelitian ini adalah:

$\mathrm{H}_{2} \quad$ : Kredibilitas celebrity endorser berpengaruh positif dan signifikan terhadap brand image

Penelitian yang dilakukan oleh Kurniawan (2016) mengungkapkan brand image berpengaruh positif dan signifikan terhadap loyalitas pengguna smartphone. Hasil penelitian yang dilakukan oleh Rizan, Saidani dan Sari, (2012) mengungkapkan hal yang serupa dimana citra merek berpengaruh terhadap loyalitas merek teh botol sosro. Rodiques dan Rahanatha (2018) mengungkapkan hal yang serupa dalam penelitiannya dimana brand image berpengaruh secara positif terhadap brand loyalty pada konsumen Iphone di Kota Denpasar, semakin baik image yang dibentuk oleh suatu merek terhadap konsumen maka loyalitas yang dirasakan konsumen terhadap merek semakin tinggi. Penelitian yang dilakukan 
oleh Alhaddad (2015) menyatakan bahwa brand image memiliki pengaruh positif yang signifikan terhadap brand loyalty.

$\mathrm{H}_{3} \quad$ : Brand image berpengaruh positif dan signifikan terhadap brand loyalty

Penelitian yang dilakukan oleh Sujana dan Giantari (2017) mengungkapkan celebrity endorser berpengaruh positif dan signifikan terhadap brand image. Analisis lain dilakukan oleh Ankasaniscara (2012) yang mengemukakan hal yang sama dimana celebrity endorser memiliki pengaruh positif dan signifikan terhadap brand image. Penelitian yang dilakukan oleh Dei dan Sukaatmadja (2015) menunjukkan bahwa kredibilitas celebrity endorser berpengaruh secara positif dan signifikan terhadap brand image pada kosmetik Etude House.

Penelitian yang dilakukan oleh Kurniawan (2016) mengungkapkan bahwa brand image berpengaruh terhadap loyalty, secara signifikan. Ini menunjukkan bahwa secara langsung citra merek Samsung tersebut berpengaruh terhadap loyalitas konsumen.

Penelitian yang diakukan oleh Widjanarko, Suharyono dan Arifin., (2016) mengemukakan celebrity endorser mempengaruhi citra merek. Besarnya kontribusi pengaruh celebrity endorser yang terdiri dari daya tarik, keahlian, kredibilitas, kepercayaan, dan kecocokan selebriti dengan merek secara simultan terhadap citra merek. Celebrity endorser dapat memerankan posisi yang vital untuk membawa sebuah merek agar dapat dikenal luas oleh masyarakat.

$\mathrm{H}_{4} \quad$ : Brand image mampu memediasi pengaruh kredibilitas celebrity endorser terhadap brand loyalty secara signifikan. 


\section{METODE PENELITIAN}

Penelitian ini dilakukan di Kota Denpasar sebagai ibukota Provinsi Bali, kota ini memiliki kepadatan penduduk mencapai 8.973 jiwa per-km² yang menyebabkan mobilitas penduduk Kota Denpasar dapat dikatakan cukup tinggi. Selain itu pemilihan lokasi ini juga dikarenakan trend-trend yang cepat berkembang dimasyarakat yang dipengaruhi dengan kecepatan akses teknologi membuat Kota Denpasar menjadi sasaran yang tepat dalam memasarkan smartphone OPPO.

Variabel bebas yang digunakan dalam penelitian ini adalah kredibilitas celebrity endorser yang disimbolkan dengan (X). Variabel mediasi yang digunakan dalam penelitian ini adalah brand image yang disimbolkan dengan (M). Variabel terikat yang digunakan dalam penelitian ini adalah brand loyalty yang disimbolkan dengan $(\mathrm{Y})$.

Tabel 2.

Indikator Penelitian

\begin{tabular}{|c|c|c|}
\hline Variabel & Indikator & Sumber \\
\hline Kredibilitas & 1. Expertise (Keahlian) & Belch\& Belch, (2018: \\
\hline Celebrity & 2. Trusthworthiness (kepercayaan) & 187) ; Pakpahan, (2017) \\
\hline Endorser (X) & 3. Attractiveness (Daya Tarik) & \\
\hline \multirow{4}{*}{$\begin{array}{l}\text { Brand Image } \\
\quad(\mathrm{M})\end{array}$} & 1. Daya ingat konsumen akan merek & Humdiana \\
\hline & 2. Kualitas & Schiffman dan Kanuk, \\
\hline & 3. Citra produk (Product Image) & $2006: 135)$, Tambrin \\
\hline & 4. Keunikan (Uniqueness) & (2010), Shimp, (2014) \\
\hline \multirow{4}{*}{$\begin{array}{l}\text { Brand Loyalty } \\
\text { (Y) }\end{array}$} & 1. Mengatakan hal yang positif (Say positive & Harianto, David. (2013). \\
\hline & thing) & Felita dan Japarianto \\
\hline & $\begin{array}{l}\text { 2. Merekomendasikan keteman (Recommend } \\
\text { friends) }\end{array}$ & $(2015)$ \\
\hline & 3. Pembelian Kembali (Continue purchasing) & \\
\hline
\end{tabular}

Sumber : Data diolah,

Populasi dalam penelitian ini adalah pengguna smartphone merek OPPO di Kota Denpasar sehingga jumlahnya tidak dapat ditentukan secara pasti. Penelitian ini menggunakan 10 indikator sehingga menggunakan ukuran sampel sebesar 
$10 \times 10=100$ responden. Sampel yag digunakan dalam penelitian ini sebesar 100 responden.

Penelitian ini menggunakan teknik analisis data berupa teknik analisis jalur atau disebut sebagai Path Analysis.

Hipotesis 1 memiliki persamaan struktural 1 sebagai berikut :

$$
\mathrm{M}=\beta_{1} \mathrm{X}+\mathrm{e}
$$

Hipotesis 2 memiliki persamaan struktural 2 sebagai berikut :

$$
\mathrm{M}=\beta_{2} \mathrm{X}+\beta_{3} \mathrm{M}+\mathrm{e} .
$$

Keterangan :

$$
\begin{array}{ll}
\mathrm{X} & =\text { Kredibilitas celebrity endorser } \\
\mathrm{M} & =\text { Brand image } \\
\mathrm{Y} & =\text { Brand loyalty } \\
\beta_{2} \beta_{2} \beta_{2} & =\text { Koefisien regresi variabel } \\
\mathrm{e} & =\text { error }
\end{array}
$$

\section{HASIL DAN PEMBAHASAN}

Data dalam penelitian ini diperoleh dari 100 responden melalui penyebaran kuesioner secara langsung. Secara garis besar, karakteristik responden dalam penelitian ini ditinjau dari beberapa variabel demografi, yang digambarkan melalui variabel jenis kelamin, usia, pendidikan dan jenis pekerjaan Tabel 3. yang menunjukkan bahwa responden dalam penelitian ini didominasi berjenis kelamin perempuan dengan selisih 40 persen dibandingkan laki-laki, dimana jumlah responden perempuan sebesar 70 orang ( 70 persen) dan jumlah responden laki-laki sebesar 30 orang (30 persen).

Berdasarkan variabel usia, jumlah responden dengan rentang usia 17- 21 tahun sebesar 71 orang ( 71 persen), responden dengan rentang usia 22- 26 tahun sebesar 15 orang (15 persen), responden dengan usia 27-31 tahun sebesar 6 orang 
(6 persen), responden dengan rentan usia 32-36 tahun sebesar 5 orang ( 5 persen), responden dengan rentang usia $>36$ tahun sebesar 3 orang.

Tabel 3.

Karakteristik demografi responden

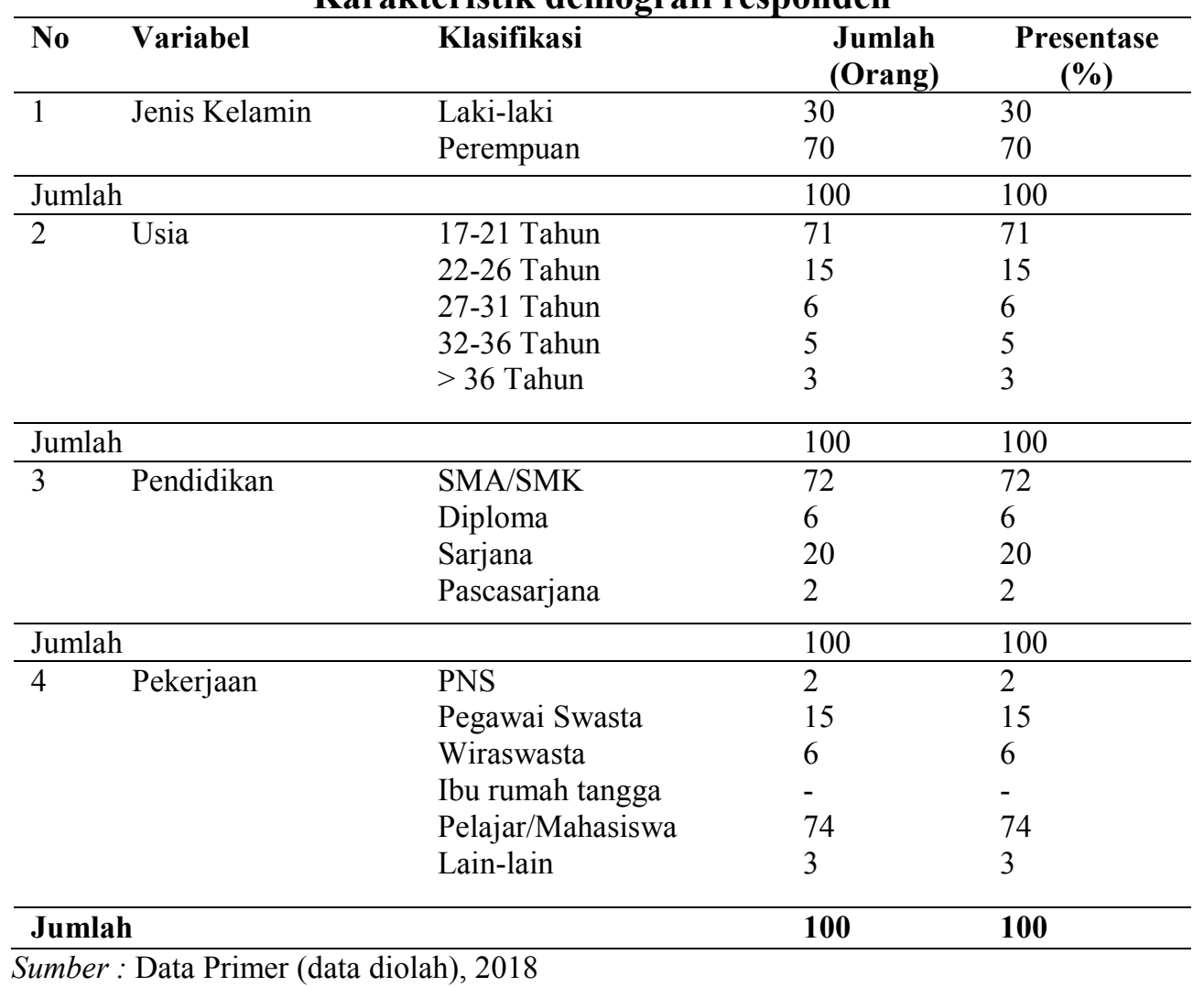

Berdasarkan variabel pendidikan, jumlah responden dengan pendidikan terakhir SMA/SMK berjumlah paling banyak yaitu sebesar 72 orang (72 persen), responden yang memiliki pendidikan terakhir diploma sebesar 6 orang (6 persen), responden yang memiliki pendidikan terakhir sarjana sebesar 20 orang (20 persen) dan yang memiliki pendidikan terakhir pascasarjana sebesar 2 orang (2 persen).

Berdasarkan variabel pekerjaan kebanyakan responden dalam penelitian ini ialah pelajar/mahasiswa yaitu sebesar 74 orang (74 persen), pada posisi ke dua ditempati oleh pegawai swasta sebesar 15 orang (15 persen), posisi selanjutkan ialah yang memiliki pekerjaan sebagai wiraswasta sebanyak 6 orang (6 persen), 
responden yang memiliki perkerjaan lain yang tidak disebutkan sebanyak 3 orang (3 persen), dan responden yang menjadi PNS sebanyak 2 orang (2 persen).

Pengujian validitas dilakukan dengan menghitung Pearson Correlation. Suatu instrument dikatakan valid apabila r Pearson Correlation terhadap skor total diatas 0,30 (Sugiyono, 2017) berikut disajikan tabel hasil uji validitas. Tabel 4. menunjukkan bahwa seluruh indikator pernyataan dalam variabel kredibilitas celebrity endorser, brand image, brand loyalty memiliki Pearason Correlation yang lebih bear dari angka 0,30. Maka dapat disimpulkan bahwa seluruh indikator variabel dalam penelitian ini adalah valid sehingga dapat digunakan sebagai instrument penelitian.

Tabel 4.

Hasil Uji Validitas

\begin{tabular}{llll}
\hline Variabel & Instrumen & $\begin{array}{l}\text { Pearson } \\
\text { Correlation }\end{array}$ & Keterangan \\
\hline Kredibilitas Celebrity Endorser & X1.1 & 0,912 & Valid \\
& X1.2 & 0,926 & Valid \\
Xrand Image & M1.3 & 0,928 & Valid \\
& M1.1 & 0,864 & Valid \\
& M1.3 & 0,848 & Valid \\
Brand Loyalty & M1.3 & 0,778 & Valid \\
& Y1.1 & 0,992 & Valid \\
& Y1.2 & 0,933 & Valid \\
& Y1.3 & 0,960 & Valid \\
\hline
\end{tabular}

Sumber: Data diolah, 2018

Pengujian reliabilitas menunjukkan sejauh mana alat pengukur dapat dipercaya atau dapat diandalkan. Uji ini dilakukan terhadap instumen koefisien Cronbach Alpha, apabila lebih besar dari 0,60 maka instrument yang digunakan reliable. Tabel 5. menunjukkan bahwa ketiga instrument penelitian yaitu variabel kredibilitas celebrity endorser, brand image, dan brand loyalty memiliki koefisien Cronbach Alpha yang lebih besar dari 0,60. Oleh karena itu dapat disimpulkan 
bahwa seluruh indikator variabel dalam penelitian ini adalah reliable, sehingga dapat digunakan sebagai instrument penelitian. Hasil uji reliabilitas instrument penelitian, disajikan pada tabel berikut:

Tabel 5.

Tabel Hasil Uji Reliabilitas

\begin{tabular}{lcc}
\hline Variabel & Cronbach Alpha & Keterangan \\
\hline Kredibilitas Celebrity Endorser & 0,911 & Reliabel \\
Brand Image & 0,838 & Reliabel \\
Brand Loyalty & 0,923 & Reliabel
\end{tabular}

Sumber : Data diolah, 2018

Data yang telah diolah dan dihitung akan menunjukkan hasil analisis seperti pada Tabel 6. dan Tabel 7.

Tabel 6.

Hasil Analisis Jalur Persamaan Regresi 1

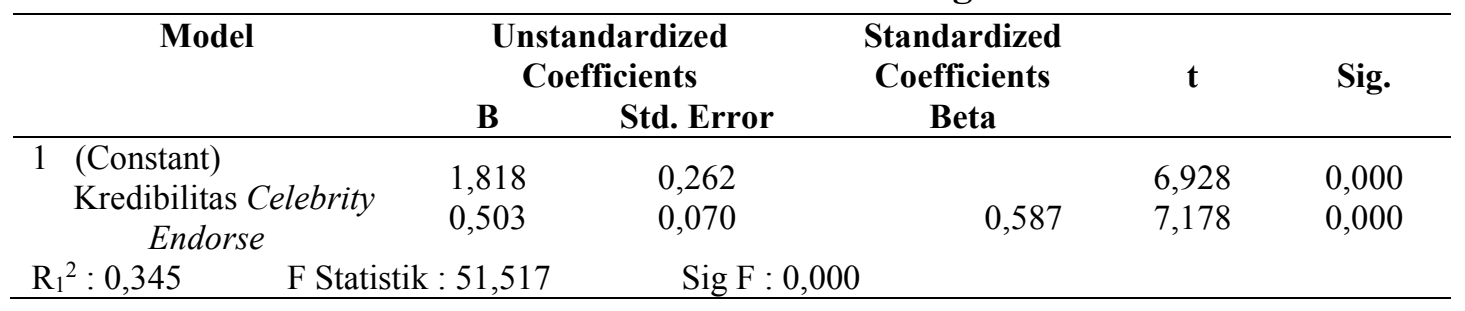

Sumber : Data diolah, 2018

Hasil analisis jalur substruktur 1 telah disajikan pada tabel 6 maka persamaan strukturalnya adalah sebagai berikut:

$$
\begin{aligned}
& M=\beta_{1} X+\varepsilon_{1} \\
& M=0,587 X
\end{aligned}
$$

Tabel 7.

\begin{tabular}{|c|c|c|c|c|c|}
\hline \multirow[t]{2}{*}{ Model } & \multicolumn{2}{|c|}{$\begin{array}{l}\text { Unstandardized } \\
\text { Coefficients }\end{array}$} & \multirow{2}{*}{$\begin{array}{c}\text { Standardized } \\
\text { Coefficients } \\
\text { Beta }\end{array}$} & \multirow[t]{2}{*}{$\mathbf{T}$} & \multirow[t]{2}{*}{ Sig. } \\
\hline & B & Std. Error & & & \\
\hline 1 (Constant) & 0,724 & 0,338 & & 2,143 & 0,035 \\
\hline Fidorse & 0,325 & 0,091 & 0,329 & 3,556 & 0,001 \\
\hline $\begin{array}{l}\text { Enaorse } \\
\text { Brand Image }\end{array}$ & 0,491 & 0,107 & 0,426 & 4,607 & 0,000 \\
\hline $\mathrm{R}_{2}^{2}: 0,455$ & \multicolumn{2}{|c|}{ F Statistik : 40,509 } & Sig. F : 0,000 & & \\
\hline
\end{tabular}

Hasil Analisis Jalur Persamaan Regresi 2

Sumber: Data diolah, 2018 
Hasil analisis jalur substruktur 2 telah disajikan pada Tabel 7 maka persamaan strukturalnya adalah sebagai berikut:

$$
\begin{aligned}
& Y=\beta_{2} X+\beta_{3} \mathrm{M}+\varepsilon_{2} \\
& \mathrm{Y}=0,329+0,426
\end{aligned}
$$

Pengaruh variabel kredibilitas celebrity endorser (X) terhadap variabel brand loyalty (Y) dengan variabel brand image (M) sebagai variabel mediasi, sebagai berikut:

$$
\begin{aligned}
\text { Pengaruh tidak langsung } & =\beta_{2} \times \beta_{3} \ldots \ldots \ldots \\
& =0,587 \times 0,426 \\
& =0,250
\end{aligned}
$$

Total pengaruh variabel kredibilitas celebrity endorser $(\mathrm{X})$ terhadap variabel brand loyalty (Y) melalui variabel brand image $(\mathrm{M})$, sebagai berikut:

$$
\begin{aligned}
\text { Pengaruh total } & =\beta_{1}+\left(\beta_{2} \times \beta_{3}\right) \ldots \ldots \ldots \ldots \ldots \ldots \\
& =0,329+(0,587 \times 0,426) \\
& =0,579
\end{aligned}
$$

Menghitung Koefisien Regresi, Standard Error (E), dan Determinasi Total ( $\left.{ }^{2}\right)$

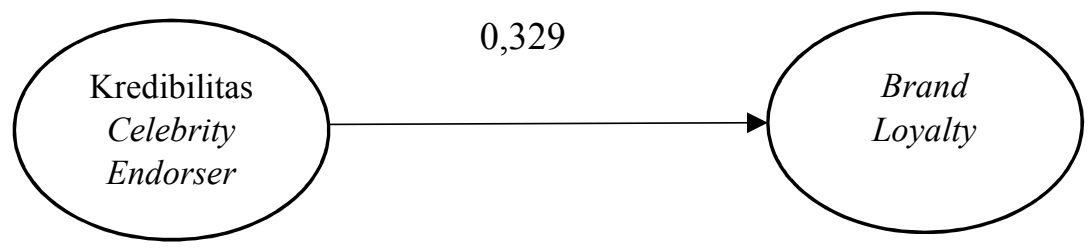

\section{Gambar 3. Model Tanpa Melibatkan Variabel Mediasi}

Hasil analisis jalur substruktur 1 dan substruktur 2 telah dihitung, maka dapat disusun model diagram jalur akhir. Nilai standard error dihitung terlebih dahulu sebelum menyusun model diagram jalur akhir, yaitu sebagai berikut:

$$
\varepsilon=\sqrt{1-\mathrm{R}^{2}}
$$




$$
\begin{array}{ll}
\varepsilon_{1} & =\sqrt{1-\mathrm{R}_{1}{ }^{2}} \\
& =\sqrt{1-0,345} \\
& =0,655 \\
\varepsilon_{2} & =\sqrt{1-\mathrm{R}_{2}{ }^{2}} \\
& =\sqrt{1-0,455} \\
& =0,545
\end{array}
$$

Standard error $(\varepsilon)$ telah dihitung, maka didapatkan hasil pengaruh error ${ }_{l}\left(\varepsilon_{1}\right)$ sebesar 0,655 dan pengaruh error $2\left(\varepsilon_{2}\right)$ sebesar 0,545 . Perhitungan nilai koefisien determinasi total adalah sebagai berikut:

$$
\begin{aligned}
\mathrm{R}^{2} \mathrm{~m} & =1-\left(\mathrm{P} \varepsilon_{1}\right)^{2}\left(\mathrm{P} \varepsilon_{2}\right)^{2} \ldots \ldots \\
& =1-(0,655)^{2}(0,545)^{2} \\
& =1-(0,429)(0,297) \\
& =1-0,127 \\
& =0,873
\end{aligned}
$$

Nilai koefisien determinasi total sebesar 0,873 yang berarti bahwa sebesar 87,3 persen variasi brand loyalty dipengaruhi oleh variasi kredibilitas celebrity endorser dan brand image, sedangkan sisanya sebesar 12,7 persen dijelaskan oleh faktor lain yang tidak dimasukkan ke dalam model

Hasil pengujian pada Tabel 6 diperoleh nilai koefisien $F \leq 0,05$ dengan koefisien signifikan $0,000 \leq 0,05$, sehingga $\mathrm{H}_{0}$ ditolak dan $\mathrm{H}_{1}$ diterima. Hasil tersebut menunjukkan bahwa kredibilitas celebrity endorser dan brand image berpengaruh secara simultan dan signifikan terhadap brand loyalty. Model persamaan struktural dalam penelitian ini telah memenuhi syarat goodness of fit melalui uji F.

Hasil analisis pengaruh kredibilitas celebrity endorser terhadap brand loyalty pada Tabel 7 diperoleh nilai koefisien beta sebesar 0,329 dengan nilai signifikan $\mathrm{t}$ 
$0,000<0,05$, sehingga $\mathrm{H}_{0}$ ditolak dan $\mathrm{H}_{1}$ diterima. Hasil tersebut menunjukkan bahwa terdapat pengaruh yang positif dan signifikan antara kredibilitas celebrity endorser dengan brand loyalty.

Hasil analisis pengaruh kredibilitas celebrity endorser dengan brand image pada Tabel 6 diperoleh nilai koefisien beta sebesar 0,587 dengan nilai signifikan $\mathrm{t}$ $0,000<0,05$, sehingga $\mathrm{H}_{0}$ ditolak dan $\mathrm{H}_{1}$ diterima. Hasil tersebut menunjukkan bahwa terdapat pengaruh yang positif dan signifikan antara kredibilitas celebrity endorser dengan brand image.

Hasil analisis pengaruh brand image dengan brand loyalty pada Tabel 7. diperoleh nilai koefisien beta sebesar 0,426 dengan nilai signifikan t $0,000<0,05$, sehingga $\mathrm{H}_{0}$ ditolak dan $\mathrm{H}_{1}$ diterima. Hasil tersebut menunjukkan bahwa terdapat pengaruh yang positif dan signifikan antara brand image dengan brand loyalty.

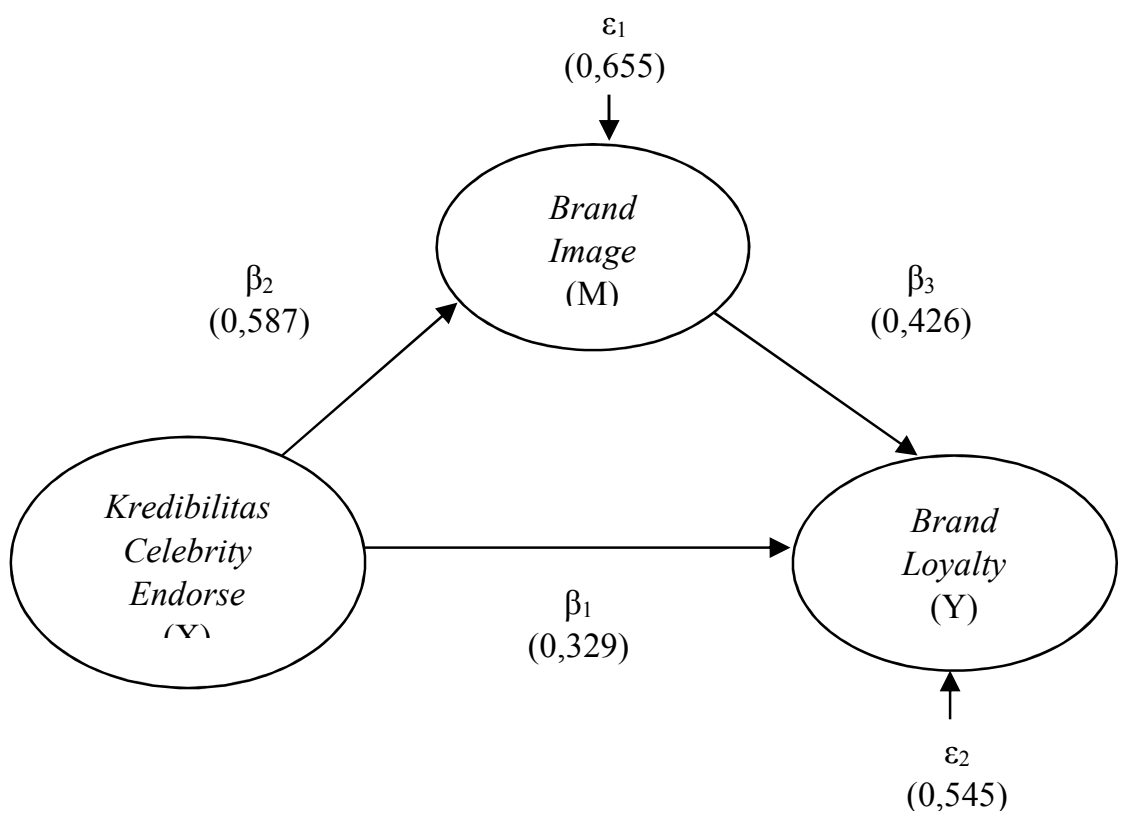

Gambar 4. Validasi Model Diagram Jalur Akhir 
Diagram jalur telah digambarkan pada Gambar 2, maka dapat dihitung besarnya pengaruh langsung, pengaruh tidak langsung serta pengaruh total antar variabel. Perhitungan pengaruh antar variabel ditunjukkan dalam Tabel 8. berikut.

Tabel 8.

Pengaruh Langsung, Pengaruh Tidak Langsung serta Pengaruh Total Kredibilitas Celebrity Endorser (X), Brand Image (M) dan Brand Loyalty (Y)

\begin{tabular}{cccc}
\hline $\begin{array}{c}\text { Pengaruh } \\
\text { Variabel }\end{array}$ & $\begin{array}{c}\text { Pengaruh } \\
\text { Langsung }\end{array}$ & $\begin{array}{c}\text { Pengaruh Tidak langsung } \\
\text { Melalui Brand Image } \\
\mathbf{( M )}=\left(\boldsymbol{\beta}_{\mathbf{2}} \times \boldsymbol{\beta}_{\mathbf{3}}\right)\end{array}$ & $\begin{array}{c}\text { Pengaruh } \\
\text { Total }\end{array}$ \\
\hline $\mathrm{X} \rightarrow \mathrm{M}$ & 0,587 & - & 0,587 \\
$\mathrm{X} \rightarrow \mathrm{Y}$ & 0,329 & $(0,587 \times 0,426)=0,250$ & 0,579 \\
$\mathrm{M} \rightarrow \mathrm{Y}$ & 0,426 & - & 0,426 \\
\hline
\end{tabular}

Sumber: Data diolah,

Hasil pada Tabel 8. menunjukkan bahwa pengaruh langsung variabel kredibilitas celebrity endorser terhadap brand loyalty memiliki nilai koefisien beta sebesar 0,329, sedangkan pengaruh tidak langsung yang dimediasi oleh brand image menunjukkan nilai koefisien beta sebesar 0,250. Hasil tersebut membuktikan bahwa brand image memediasi pengaruh kredibilitas celebrity endorser dengan brand loyalty dengan pengaruh total yang diperoleh sebesar 0,579.

Uji Sobel dilakukan untuk menguji signifikansi pengaruh tidak langsung variabel kredibilitas celebrity endorser $(\mathrm{X})$ terhadap variabel brand loyalty $(\mathrm{Y})$ melalui variabel brand image (M). Uji Sobel dihitung dengan menggunakan aplikasi Microsoft Excel 2010. Nilai koefisien z jika lebih besar dari 1,96, maka variabel brand image sebagai variabel mediasi dalam penelitian ini dinilai secara signifikan mampu memediasi pengaruh pengaruh celebrity endorser terhadap brand loyalty. Uji Sobel dihitung dengan persamaan sebagai berikut:

$\mathrm{Z} \quad=\frac{\mathrm{ab}}{\sqrt{\mathrm{b}^{2} \mathrm{Sa}^{2}+\mathrm{a}^{2} \mathrm{Sb}^{2}+\mathrm{Sa}^{2} \mathrm{Sb}^{2}}}$ 
Keterangan:

$$
\begin{array}{ll}
\mathrm{a} & =0,587 \\
\mathrm{~S}_{\mathrm{a}} & =0,07 \\
\mathrm{~b} & =0,426 \\
\mathrm{~S}_{\mathrm{b}} & =0,107 \quad \mathrm{ab} \\
\mathrm{Z} & =\frac{(0,587)(0,426)}{\sqrt{\mathrm{b}^{2} \mathrm{Sa}^{2}+\mathrm{a}^{2} \mathrm{Sb}^{2}+\mathrm{Sa}^{2} \mathrm{Sb}^{2}}} \\
\mathrm{Z} & =\frac{0,2501}{\sqrt{(0,426)^{2}(0,07)^{2}+(0,587)^{2}(0,107)^{2}+(0,07)^{2}(0,107)^{2}}} \\
\mathrm{Z} & =\frac{0,0009+0,039+0,0001}{\sqrt{0,0009+2501}} \\
\mathrm{z} & =\frac{0,27}{0,07} \\
\mathrm{z} & =3,57
\end{array}
$$

Hasil Uji Sobel yang telah dihitung menunjukkan bahwa nilai koefisien z adalah 3,57 $>1,96$ dengan tingkat signifikansi $0,0003<0,05$, sehingga $\mathrm{H}_{0}$ ditolak dan $\mathrm{H}_{1}$ diterima. Hasil tersebut mengartikan bahwa brand image sebagai variabel mediasi dinilai secara signifikan mampu memediasi pengaruh kredibilitas celebrity endorser terhadap brand loyalty.

Pengaruh antara kredibilitas celebrity endorser terhadap brand loyalty dalam penelitian ini diperoleh nilai koefisien beta sebesar 0,329 dengan tingkat signifikansi $0,000 \leq 0,05$ sehingga $\mathrm{H}_{0}$ ditolak dan $\mathrm{H}_{1}$ diterima, yang mengindikasikan bahwa kredibilitas celebrity endorser berpengaruh positif dan signifikan terhadap brand loyalty. Hasil tersebut menunjukkan bahwa semakin baik kredibilitas celebrity endorser yang dimiliki perusahaan untuk mempromosikan produk smartphone OPPO, maka semakin tinggi tingkat brand loyalty pada produk smartphone merek OPPO pada konsumen.

Hasil penelitian ini diperkuat dengan penelitian sebelumnya yang dilakukan oleh Spry dan Pappu (2011) serta Audy, Razan dan Khalil (2015) dan membantah 
penelitian yang dilakukan oleh Agung dan sholikah (2017) dan Susanti (2011). Hal ini berarti, dengan celebrity endorser yang memiliki kredibilitas yang semakin baik dimata konsumen maka dapat meningkatkan cerminan dari tingkat keterikatan konsumen terhadap produk sehingga konsumen akan memiliki ketertaikan terhadap produk tersebut karena kepercayaan konsumen akan produk melalui celebrity endorser

Pengaruh antara kredibilitas celebrity endorser dengan brand image telah diuji dalam penelitian ini, dimana nilai koefisien beta diperoleh sebesar 0,587 dengan tingkat signifikansi $0,000 \leq 0,05$ sehingga $\mathrm{H}_{0}$ ditolak dan $\mathrm{H}_{1}$ diterima, yang mengindikasikan bahwa kredibilitas celebrity endorser berpengaruh positif dan signifikan terhadap brand image. Hasil tersebut menunjukkan bahwa semakin baik kredibilitas yang dimiliki kredibilitas celebrity endorser dalam mempromosikan produk smartphone merek OPPO, maka tingkat brand image pada produk smartphone merek OPPO juga semakin tinggi.

Hasil penelitian ini sesuai dengan penelitian sebelumnya yang dilakukan oleh Sujana dan Giantari (2017), Komala dan Ekowati (2017), Rini (2012), Putra dan Sulistyawati (2015), dan Byberg et al. (2015). Penelitian Komala menggunakan metode penelitian purposive sampling, tingkat signifikansi $0,000 \leq 0,05$ sehingga $\mathrm{H}_{0}$ ditolak dan $\mathrm{H}_{2}$ diterima dan hasil yang didapat adalah kredibilitas celebrity endorser berpengaruh positif terhadap brand image dapat diterima. Hal ini berarti bahwa dengan meningkatnya kredibilitas celebrity endorser yang baik akan meningkatkan persepsi terkait citra merek di mata konsumen. 
Pengaruh antara brand image dengan brand loyalty dalam penelitian ini diperoleh nilai koefisien beta sebesar 0,426 dengan tingkat signifikansi $0,000 \leq 0,05$ sehingga $\mathrm{H}_{0}$ ditolak dan $\mathrm{H}_{1}$ diterima, yang mengindikasikan bahwa brand image berpengaruh positif dan signifikan terhadap brand loyalty. Hasil tersebut menunjukkan bahwa semakin tinggi tingkat brand image terkait produk Smartphone merek OPPO, maka semakin tinggi pula tingkat brand loyalty konsumen pada produk smartphone merek OPPO.

Hasil penelitian ini sesuai dengan penelitian sebelumnya yang dilakukan oleh Kurniawan (2016), Ratri (2017), Rizan, Saidani dan Sari (2012), dan Rodiques dan Rahanatha (2018) yang memperoleh hasil brand image berpengaruh positif dan signifikan terhadap brand loyalty. Ketertarikan atau minat akan membentuk sebuah persepsi terhadap brand image suatu produk dalam proses pengambilan keputusan seseorang. Hal ini akan mendorong seseorang memutuskan pembelian yang berujung pada loyalitas. Produk yang memiliki image yang baik akan menumbulkan loyalitas pelanggan pada merek.

Peran brand image dalam memediasi pengaruh kredibilitas celebrity endorser dengan brand loyalty produk smartphone merek OPPO telah diuji dalam penelitian ini. Hasil uji pengaruh kredibilitas celebrity endorser terhadap brand loyalty semula bernilai 0,329 , kemudian setelah adanya brand image sebagai variabel mediasi, nilai pada pengaruh kredibilitas celebrity endorser terhadap brand loyalty meningkat menjadi sebesar 0,579. Hasil tersebut menunjukkan bahwa brand image memediasi secara parsial pengaruh kredibilitas celebrity endorser terhadap brand loyalty secara parsial. Uji Sobel yang telah dilakukan memperkuat hasil tersebut 
dengan nilai koefisien z yang diperoleh adalah 3,57 > 1,96, yang mengindikasikan bahwa brand image dinilai mampu memediasi pengaruh kredibilitas celebrity endorser terhadap brand loyalty produk smartphone merek OPPO.

Hasil penelitian ini sejalan dengan penelitian yang dilakukan oleh Dei dan Sukaatmadja (2015) dimana kredibilitas celebrity endorser berpengaruh secara positif dan signifikan terhadap brand image pada kosmetik Etude House. Penelitian yang dilakukan oleh Kurniawan (2016) mengungkapkan bahwa brand image berpengaruh terhadap loyalty, secara signifikan serta penelitian yang dilakukan oleh Spry dan Pappu (2011) dalam penelitiannya mengatakan semakin tinggi kredibilitas celebrity endorser, semakin tinggi kemungkinan iklan mencipakan loyalitas merek untuk produk yang dipromosikan oleh selebriti. Semakin baik kredibilitas yang dimiliki oleh seorang celebrity endorser akan menciptakan image yang semakin positif bagi produk dimata konsumen sehingga loyalitas konsumen terhadao suatu produk akan terjadi

\section{SIMPULAN}

Berdasarkan pembahasan hasil penelitian yang telah dilakukan, maka dapat disimpulkan bahwa kredibilitas celebrity endorser berpengaruh positif dan signifikan terhadap brand loyalty. Hasil ini berarti semakin tinggi kredibilitas yang dimiliki celebrity endorser yang mengiklankan produk, maka akan meningkatkan brand loyalty yang dimiliki produk tersebut. Kredibilitas celebrity endorser berpengaruh positif dan signifikan terhadap brand image. Hasil ini berarti semakin tinggi kredibilitas yang dimiliki celebrity endorser yang mengiklankan produk, maka semakin tinggi pula brand image yang dimiliki produk tersebut. Brand image 
berpengaruh positif dan signifikan terhadap brand loyalty. Hasil ini berarti semakin tinggi citra dari merek yang dimiliki oleh produk maka akan meningkatkan loyalitas merek di kota Denpasar. Kredibilitas celebrity endorser mampu memediasi pengaruh kredibilitas celebrity endorser terhadap brand loyalty. Hal ini berarti bahwa brand image yang terbentuk pada produk handphone OPPO turut mempengaruhi kredibilitas celebrity endorser terhadap brand loyalty handphone merek OPPO di kota Denpasar.

Saran yang dapat diberikan berdasarkan kesimpulan yang didapat adalah sebagai berikut, indikator selebriti ahli dalam menyakinkan produk smartphone memiliki kualitas yang baik merupakan variabel dari kredibilitas celebrity endorser yang memperoleh skor terendah, saran bagi perusahaan OPPO sebaiknya lebih menonjolkan spesifikasi produknya dengan membuat sebuah iklan yang berisikan bagian kelebihan smartphone baik dalam segi material maupun software yang membedakan produknya dengan yang lain, sehingga akan meningkatkan minat calon konsumen untuk membeli produk smartphone merek OPPO.

Indikator kualitas produk smartphone lebih baik dibandingkan merek lain merupakan variabel dari brand image yang memperoleh skor terendah, saran bagi pihak produsen ialah menonjolkan kelebihan yang di fokuskan pada produk sehingga produk memiliki story yang berbeda dengan para pesaing, selain itu perusahaan dapat mempernyaman konsumen dengan meningkatkan pelayanan di service center sehingga meningkatkan citra merek yang dimiliki oleh produk dan produk menjadi semakin baik di mata konsumen hal ini akan mendorong terciptanya rasa kepercayaan konsumen terhadap produk. 
Indikator dari pernyataan akan merekomendasikan kepada kenalan tentang produk merupakan variabel dari brand loyalty yang memperoleh skor terendah, maka sebaiknya pihak produsen OPPO menciptakan sebuah program untuk tetap menjaga loyalitas dimana dalam program tersebut OPPO akan menampilkan setiap spesifikasi produk dan kelebihan yang dimiliki disamping itu pemberian hadiah seperti voucher atau cashback akan cukup membantu meningkatkan loyalitas. Hal tersebut sebaiknya dilakukan secara rutin dan berkala sehingga pasar tidak akan berpaling.

Terdapat beberapa keterbatasan dari penelitian ini diantaranya, ruang lingkup penelitian terbatas pada wilayah Kota Denpasar, sehingga hasil penelitian ini tidak dapat digeneralisasi untuk konsumen di wilayah yang lebih luas. Mengingat penelitian ini dilakukan dalam jangka waktu tertentu sedangkan lingkungan mengalami perubahan, maka penelitian ini penting dilakukan di masa yang akan datang.

\section{REFERENSI}

Agung, A., Solikhah., \& Pamungkas, B. (2017). Analisis Pengaruh Kredibilitas Selebriti Endorser dan Kredibilitas Merek Terhadap Loyalitas Merek. Proceeding National Conference on Applied Business, 8(5), 72-80

Alhaddad, A.(2015). A Structural Model of The Relationships Between Brand Image, Brand Trust and Brand Loyalty. International Journal of Management Research \& Revie, 5(1), 137-144

Audi,M., Razan A M., \& Khalil, G. (2015). The effect of celebrity endorsement on creating brand loyalty : An Application on the Lebanese Cosmetic Sector's Demand. International Journal of Business Management and Economic Research. 6(5), 273-287

Apejoye,A. (2013). Influence of Celebrity Endorsement of Advertisement on Student's Purchase Intention. Mass Communication and Journalism, 3(3), $1-7$ 
Ankasaniscara, P., (2012). Analisis Pengaruh Celebrity Endorsement Pada Brand Image Terhadap Keputusan Pembelian Studi Kasus : Peter Says Denim, Tesis, Program Magister Manajemen Fakultas Ekonomi Universitas Indonesia, Jakarta.

Arsita, G. A. P. \& Purnami, Ni. M. (2015). Peran Persepsi Nilai dalam Memediasi Pengaruh Kredibilitas Celebrity Endorser pada Niat Beli Produk Kosmetik Maybelline di Kota Denpasar. E-Jurnal Manajemen Universitas Udayana. 9(2), 123-134

Aziz, S., Usman, G., \&cAbdullah, N. (2013). Impact of celebrity credibility on advertising effectiveness. Pakistan Journal of Commerce and Social Sciences. 7(1), 107-127

Baniya, R. (2017). Componets of Celebrity Endorsement Affecting Brand Loyalty of Nepali Customer. Journal of Business and Management Research. 2(1\&2). 52-65

Belch, G.E \& Belch, M A. (2018). Advertising and Promotion: An Integrated Marketing Communications Perspective, Eleventh edition. New York: The McGraw Hill Education.

Belic, S and Emelie, J. (2012) .Guerilla Marketing (And its effects on Consumer Behavior). Sweden: Kristiantad University, School of Healthy and Sociaty.

Byberg, A., Hansen, J., Basic, M., \& Nazir, I. (2015). Celebrity Endorsement's Impact on Brand Image and Sales (A ase Study on Volvo Cars Sweden). Thesis.Jonkoping International Business School

Dei, G. A. Theoria \& Sukaatmadja, I P. G. (2015). Peran Brand Image Memediasi Pengaruh Kredibilitas Celebrity Endorser Terhadap Purchase Intention. EJurnal Manajemen Universitas Udayana, 4(5), 1206-1228

Dix, S., Ian, P., \& Sonia P. (2010). "Bend it like Beckham”: The Influence Of Sports Cleberities On Young Adult Consumers. International Journal of Young Consumers.11(1), 36-46

Felita, C \& Japarianto, E. (2015). Analisa Pengaruh Customer Experience tehadap Curstomer Loyalty dengan Customer Engagement dan Customer Trust sebagai Variabel Interning di The Body Shop. Jurnal Manajemen Pemasaran Perta. 1(1), 1-10

Harianto, D \& Subagio, Dr. H. (2013). Analisa Pengaruh Kualitas Layanan, Brand Image, dan Atmosfer terhadap Loyalitas Konsumen dengan Kepuasan Konsumen sebagai Variabel Intervening Konsumen Kedai Deja-Vu Surabaya. Jurnal Manajemen Pemasaran Petra. 1(1), 1-8

Humdiana. (2005). Strategi Pemasaran. Jakarta: PT Gramedia Pustaka Mizan Pustaka. 
Kurniawan, I. (2016). Pengaruh Brand Image Terhadap Loyalitas Yang Dimediasi Brand Trust Pada Pengguna Smartphone. Jurnal STIE PGRI Dewantara Jombang, 14(2), 100-105

Komala, J A., Ekowati, T., \& Budiyanto. (2017). Pengaruh Kredibilitas Celebrity Endorser terhadap Purchase Intention yang dimediasi oleh Brand Image (Studi pada Konsumen Warda di Purworejo). Jurnal Manajemen Bisnis, 13(2B), 1-16

Kotler, P \& Garry, A. (2014). Principles of Marketing. New Jersey : Pearson Education Limited.

Lazarevic, V. (2011). Encouraging Brand Loyalty in Fickle Generation Y Consumers. Journal of young Consumenrs. 13(1), 45-61

Lomboan, S. (2013). The Impact Of Celebrity Endorsement On Brand Image. Jurnal EMBA. 1(3), 788-795

Pakpahan, E. S. B. (2017). Pengaruh Kredibilitas Celebrity Endorser Terhadap Keputusan Pembelian dan Kepuasan Konsumen YOU-C 1000 Vitamin CDI Kota Pekanbaru. JOMFekon, 4(1), 721-734

Putra, I K. T. D \& Sulistyawati, E. (2015). Peran Brand Image Dalam Memediasi Pengaruh Celebrity Endorser Terhadap Niat Beli. E-Jurnal Manajemen Universitas Udayana, 4(6), 1722-1734

Rini, E. S. (2012). Pengaruh Agnes Monica Sebagai Celebrity Endorser terhadap Pembentukan Brand image Honda Vario. Bisma Junal Bisnis dan Manajemen, 6(1), 1-8

Rodiques, Y dan Rahanatha, G. B. (2018). Peran Brand Trust Memediasi Hubungan Brand Image Dengan Brand Loyalty (Studi Pada Konsumen Iphone Di Kota Denpasar). E-Jurnal Manajemen Universitas Udayana, 7(3), 1310-1338

Rizan, M., Saidani, B., \& Sari, Y. (2012). Pengaruh Brand Image dan Brand Trust Terhadap Brand Loyalty Teh Botol Sosro. Jurnal Riset Manajemen Sains Indonesia, 3(1), 1-17

Sujana, M. S. A. S \& Giantari, I G. A. K. (2017). Peran Brand Image Memediasi Hubungan Celebrity Endorser Dengan Purchase Intention. Jurnal Forum Keuangan dan Bisnis Indonesia, 6, 313-324

Schiffman, L.G., \& Kanuk L.L. (2006).Consumer Behavior. $7^{\text {th }}$ Edition. New Jersey : Prentice Hall.

Spry A., Pappu R., T. \& Cornwell T.B. (2011). Celebrity endorsement, brand credibility and brand equity. Jurnal of marketing, 4(5), 882-909

Sharif, R., Raza, I., \& Rehman, M.Z. (2011). Analysis of The factors Affecting Customers' Purchase Intention: The Mediating Role of Percieved Value. African Journal of Business Management, 5 (26), 10577-10585 
Shimp, T. A. (2010). “Advertising, Promotion, and other aspects of Integrated Marketing Communications", Mason, $\mathrm{OH}$ : South-Western Cengage Learning, eight edition.

Sari, N. K. L dan Santika, I W. (2017). Pengaruh Brand Image, Brand Asociation, dan Brand Awareness Terhadap Repurchase Intention Produk Smartphone Merek Asus. E-Jurnal Manajemen Universitas Udayana, 6(8), 4099-4126

Tambrin, M. (2010). Pengaruh Brand image Terhadap Pelanggan Kartu Simpati Terhadap Kepuasan Mahasiswa Universitas Trunojoyo Madura. Jurnal Pemasaran, 4(1), 61-62

Ugwuanyi, C. C., Okeke, C. V., \& Emezue, L N. (2018). Celebrity Advertising, Brand Awareness and Brand Recognition : A Structural Equation Modelling Approach. European Journal of Business and Management. 10(28).

Wang, Ya-Hui., \& Cing-Fen Tsai. (2014). The Relationship Between Brand Image and Purchase Intention: Evidence From Award Winning Mutual Funds. The International Journal of Business and Finance Research, 8 (2), 27-40

Wijanarko, P., Suharyono., \& Zainul, A. (2016). Pengaruh Celebrity Endorser Terhadap Citra Merek Dan Dampaknya Pada Keputusan Pembelian (Survei kepada Pengunjung Warung Kopi Kriwul, Kelurahan Merjosari, Kecamatan Lowokwaru, Kota Malang yang Pernah Melihat Iklan dan Membeli TOP Coffee). Jurnal Administrasi Bisnis, 34(1), 165-171

https://id.wikipedia.org/wiki/OPPO_Electronics (Diakses 6 Maret 2018)

https://www.idc.com/promo/smartphone-market-share/vendor (Diakses 23 Maret 2018) 